\title{
Robust and Generic Control of Full-Bridge Modular Multilevel Converter High-Voltage DC Transmission Systems
}

\author{
Grain Philip Adam and Innocent Ewean Davidson
}

\begin{abstract}
This paper presents the theoretical basis of the control strategy that allows the cell capacitor voltage regulation of the full-bridge modular multilevel converter (FBMMC) to be controlled independent of its de link voltage. The presented control strategy permits operation with reduced dc link voltage during permanent pole-to-ground de fault, and controlled discharge and recharge of the HVDC links during shutdown and restart following clearance of temporary pole-topole dc faults. Additionally, it allows voltage source converter based HVDC links that employ FB-MMC to be operated with both positive and negative dc negative dc link voltages. This feature is well suited for hybrid HVDC networks, where the voltage source converters are operated alongside the line commutating current source converters, without any compromise to the power reversal at any terminals. The usefulness of the presented control strategy is demonstrated on full-scale model of HVDC link that uses FB-MMC with 101 cells per arm, considering the cases of pole-to-ground and poleto-pole de faults.
\end{abstract}

Index-Terms - DC fault reverse blocking, full and half bridge modular multilevel converter, High-voltage dc transmission systems, and multi-terminal high-voltage dc networks.

\section{INTRODUCTION}

$\mathrm{R}$ ecently there are several voltage source converter (VSC) topologies being proposed aim to improve dc fault survival of point-to-point and multi-terminal HVDC transmission systems[1-8]. Half-bridge modular multilevel converter (HB-MMC) is widely adopted in recent years; because its distributed cell capacitors do not contribute discharge current to dc fault when converter switches are blocked [7, 9-18]. As a result the magnitude of transient dc fault current is greatly reduced compared to that of conventional VSC topologies with concentrated input dc link capacitors such as two-level and neutral-point clamped converters[3, 4, 6, 9, 19-21]. However, HB-MMC is unable to stop ac grid contribution to the dc fault current through its freewheeling diodes. This makes its dc fault survival is increasingly relies on the availability of fast acting dc circuit breakers as suggested in [9, 22-25]. Otherwise, HB-MMC freewheeling diodes may fail from excessive current stresses. FB-MMC offers an invaluable feature of dc fault current limiting, and shares many other attributes with HBMMC; but it has been widely dismissed on the ground of high semiconductor losses [22, 26-31].

G. P. Adam is with the Department of Electronic and Electrical Engineering, University of Strathclyde, Glasgow, G1 1XW UK (e-mail: grain.adam@eee.strath.ac.uk).

Innocent Ewean Davidson is with Eskom Centre of Excellence in HVDC and Smart Grid Research, within School of Engineering, University of KwaZulu-Natal, Durban, South Africa ( Davidson@ukzn.ac.za)
Mixed cells MMC (50\% of the cells are half-bridge and remaining $50 \%$ are full-bridge) is suggested as an alternative to FB-MMC in attempt to achieve dc fault current limiting feature at reduced semiconductor losses [5, 32]. This approach is appeared to be attractive because it combines the attributes of both HB-MMC and FB-MMC such as modularity and internal fault management. Alternative arm modular multilevel converter (AA-MMC) discussed in $[3,7$, $8,33,34]$ offers dc fault current limiting feature with similar level of semiconductor losses as mixed cells MMC, but with smaller footprint [5, 35]. However, smooth current commutation between upper and lower arms of the AAMMC is seemed to be challenging, especially when AAMMC exchanges large reactive power with the ac grid. Additionally, AA-MMC is expected to have large transient $\mathrm{dc}$ fault current from discharge of its concentrated input $\mathrm{dc}$ link capacitor as dc link voltage collapses during dc short circuit faults. References $[4,5]$ have shown that the threelevel and five-level cells MMCs presented in [23, 36-38] offer dc fault limiting feature, with similar level of semiconductor losses and converter footprint as the mixed cells MMC. But they acquire dc fault current limiting feature at greater complexity of the control and power circuit compared to mixed cells MMC.

This paper explores manipulation of insertion function dc bias to enable reduced dc voltage operation of the HVDC links that employ FB-MMC during permanent pole-toground dc faults, and to facilitate controlled discharge and recharge of the dc link during system shutdown and restart following clearance of temporary dc faults. Additionally, this paper uses a generic electromagnetic model of the FBMMC to demonstrate the benefits of manipulation insertion function dc bias at system level, considering the case of fullscale HVDC link, where each converter terminal is a FBMMC with 101 cells per arm. It has been shown that the adjustment of the insertion function dc bias improves transient response of the HVDC link being studied, including its de fault ride through capability.

\section{FULL-BRIDGE MODULAR MULTILEVEL CONVERTER (FB- $\mathrm{MMC})$}

A) Theoretical basis of FB-MMC modulation

Figure 1 shows a generic three-phase FB-MMC with ' $N$ ' cells per arm and input dc link voltage of $V_{d c}$ when it is connected to ac grid through an interfacing transformer. Assume the voltage drops in the upper and lower arm reactors are negligible compared to $V_{d c}$, the output phase voltage at output pole ' $a$ ' relative to supply mid-point ' $o$ ' 
This paper is a postprint of a paper submitted to and accepted for publication in IEEE Transaction on Power Electronics and is subject to Institution of Electrical and Electronic Engineering Copyright. The copy of record is available at IEEE Xplore Digital Library

can be expressed as: $v_{a 0}(t)=\frac{1}{2} V_{d c}-\gamma \sum_{j=1}^{N} v_{c j}$, where $v_{c j}$

represents capacitor voltage of cell $j^{\text {th }}$ and $\gamma$ is insertion or modulation function. Insertion function for the FB-MMC upper arm is $\gamma(t)=\frac{1}{2}\left(\alpha_{d}-m \sin (\omega t+\delta)\right.$, where ' $m$ ' is the modulation index; ' $\alpha$ ' stands for insertion function dc bias; and ' $\delta$ ' is the phase shift between phase ' $a$ ' fundamental voltage at converter terminal ' $v_{a o}$ ' and voltage ' $v_{a}$ ' at the point of common coupling. Recently, it has been recognized that the cell capacitor voltages of the full-bridge MMC can be regulated independent of the dc link voltage, should bipolar capability of each individual FB cell is fully exploited[22]. This allows insertion function' $\gamma$ ' of the FBMMC and its dc component to be varied over extended range of $-1 \leq \gamma \leq 1$ and $-1 \leq \alpha_{d} \leq 1$ respectively. When the sum of the cell capacitor voltages in each MMC arm is regulated at ' $V_{\text {cref }}$ ', the voltage developed across upper and lower arms of phase ' $a$ '

are:

$v_{a 1}(t)=\frac{1}{2} V_{d c}-\frac{1}{2} m V_{c r e f} \sin (\omega t+\delta)=\frac{1}{2} V_{c r e f}\left[\alpha_{d}-m \sin (\omega t+\delta)\right] \quad$ and

$v_{a 2}(t)=\frac{1}{2} V_{d c}+\frac{1}{2} m V_{c r e f} \sin (\omega t+\delta)=\frac{1}{2} V_{c r e f}\left[\alpha_{d}+m \sin (\omega t+\delta)\right]$,

where $\alpha_{d}=V_{d c} / V_{\text {cref. }}$. Observe that when ' $V_{\text {cref }}$ ' is regulated close or equal to de link voltage $\left(V_{d c}\right)$ as it will be during normal operation for practical reasons, $\alpha_{d} \approx 1$ as in HB-MMC case (all cells are inserted with positive polarity); $\alpha_{d} \approx 0$ when $V_{d c} \approx 0$ during pole-to-pole dc short circuit fault $(50 \%$ of cells are inserted with positive polarity and remaining $50 \%$ with negative polarity); and $\alpha_{d}=-1$ when polarity of the input dc link voltage is reversed (all cells to be inserted with negative polarity). When the cell capacitor voltage regulation is decoupled from the converter input dc link voltage as being pursued in this paper, the maximum peak fundamental voltage can be synthesized during normal operation is $V_{m 1}=\left|v_{a 0}(t)\right|=\left|\frac{1}{2} V_{d c}-\gamma \sum_{j=1}^{N} v_{c j}\right|=V_{c r e f}-\frac{1}{2} V_{d c}$, with $\gamma=1$ or -1 (positive $\gamma$ corresponds to number of cell capacitors to be inserted with positive polarity, and the opposite is true). Notice that when the dc link voltage collapses to zero during pole-to-pole dc fault, insertion function is limited to $1 / 2 \leq \gamma \leq 1 / 2$; and in this case, the maximum peak fundamental voltage can synthesized is $1 / 2 V_{\text {cref }}$, which is almost the same as in normal operation should ' $V_{\text {cref }}$ ' is set to be equal to nominal input dc operating voltage ' $V_{d c 0}$ '. This shows when cell capacitor voltage regulation of the FB-MMC is decoupled from the input dc link voltage level, the cell capacitors of each arm act as virtual dc link, including during collapse of the actual dc link voltage. This permits ac voltage at converter terminal to be synthesized independent of input de link voltage. This feature allows FB-MMC to be controllable even when the input dc link is lower than the grid voltage. Notice that the insertion function of each arm varies within $0 \leq \gamma \leq 1$ and $-1 \leq \gamma \leq 0$ during normal operation with positive and negative input dc link voltage respectively. The above discussions have shown that the input dc link voltage of the FB-MMC can be varied from $V_{d c 0}$ to $-V_{d c}$, without loss of converter control, benefiting of the use of the cell capacitors of each converter arm as a virtual dc link.

\section{B) Converter control}

Figure 2 summaries control systems of the FB-MMC being used in this paper. Observe that the loops that regulate AC power/or dc link voltage, reactive power/or ac voltage and ac currents in synchronous reference frame set the insertion function ac component, and provide over-current protection during ac network faults. Whilst the loops that regulate cell capacitor voltages independent of converter $\mathrm{dc}$ link and common mode currents that flow in the converter arms set the insertion function dc bais, and provide overcurrent protection during dc side faults. The most inner loop uses amplitude (staircase) modulation to generate the gating signals for switches of the FB-MMC, with Marquardt capacitor voltage balancing that rotates the cell capacitors based on their voltage magnitudes and polarity of the arm currents. The loops that regulate cell capacitor voltages are designed as follows:

\section{A) Common mode current}

Differential equations that describe the dynamics of FBMMC upper and lower arm currents for phase ' $a$ ' are:

$$
\begin{aligned}
& L_{d} \frac{d i_{a 1}}{d t}=\frac{1}{2} V_{d c}-v_{a 1}-R_{d} i_{a 1}-v_{a 0} \\
& L_{d} \frac{d i_{a 2}}{d t}=\frac{1}{2} V_{d c}-v_{a 2}-R_{d} i_{a 2}+v_{a 0}
\end{aligned}
$$

Where $i_{a 1}$ and $i_{a 2}$ are phase 'a' upper and lower arm currents; $v_{a 1}$ and $v_{a 2}$ are voltages developed across converter upper and lower arms cell capacitors of phase 'a'; and $R_{d}$ and $L_{d}$ are resistance and inductance of the upper and lower arm reactors. After adding (2) to (1) and recall that $v_{a 1}$ and $v_{a 2}$ are $v_{a 1}=\frac{1}{2} V_{c}\left[m_{d}-m \sin (\omega t+\delta)\right] \quad$ and $\quad v_{a 2}=\frac{1}{2} V_{c}\left[m_{d}+m \sin (\omega t+\delta)\right]$, equation (3) is obtained:

$$
L_{d} \frac{d i_{c o m}}{d t}=\frac{1}{2} V_{d c}-\frac{1}{2} m_{d} V_{c}-R_{d} i_{c o m}
$$

Where the common mode current $i_{c o m}$ is: $i_{c o m}=\frac{1}{2}\left(i_{a 1}+i_{a 2}\right)$ and $V_{c}=\frac{1}{2}\left[\sum_{j=1}^{N} v_{c u j}+\sum_{j=1}^{N} v_{c l j}\right]$. To facilitate control design, let $u_{\text {com }}=1 / 2 V_{d c^{-1} / 2 m_{d}} V_{c}$ and $u_{\text {com }}$ will be obtained from proportional-integral (PI) controller as:

$$
u_{\text {com }}=k_{p}\left(i_{\text {com }}^{*}-i_{\text {com }}\right)+k_{i} \int\left(i_{\text {com }}^{*}-i_{\text {com }}\right) d t
$$

After replacing the integral part of (4) by $z_{c o m}$, and further algebraic and Laplace manipulations, the following transfer function is obtained: $\frac{i_{\text {com }}(s)}{i_{\text {com }}^{*}(s)}=\frac{\frac{k_{p}}{L_{d}} s+\frac{k_{i}}{L_{d}}}{s^{2}+\frac{\left(k_{p}+R_{d}\right)}{L_{d}} s+\frac{k_{i}}{L_{d}}}$. This transfer function allows the initial controller gains to be selected as $k_{i}=\omega_{n}^{2} L_{d}$ and $k_{p}=2 \xi \omega_{n} L_{d}-R_{d}$ for given timedomain specifications such as settling time or using frequency domain. From the above definition of the $u_{c o m}, m_{d}$ is obtained considering the feed-forward term of $1 / 2 V_{d c}$ as: $m_{d}=2\left(1 / 2 V_{d c}-u_{c o m}\right) / V_{c}$. 
This paper is a postprint of a paper submitted to and accepted for publication in IEEE Transaction on Power Electronics and is subject to Institution of Electrical and Electronic Engineering Copyright. The copy of record is available at IEEE Xplore Digital Library

\section{B) Cell capacitor voltage}

The differential equations that describe the cell capacitor dynamics of the upper and lower arms of phase ' $a$ ' as an example $\quad$ are: $\frac{d}{d t} \sum_{j=1}^{N} \frac{1}{2} C v_{c u j}^{2}=i_{a 1} \times \gamma_{1}^{a} \sum_{j=1}^{N} v_{c u j}$ and $\frac{d}{d t} \sum_{j=1}^{N} \frac{1}{2} C v_{c l j}^{2}=i_{a 2} \times \gamma_{2}^{a} \sum_{j=1}^{N} v_{c l j}$. With proper control, the cell capacitor voltages of the upper arm vary together with relatively small errors, and the same is applicable to the lower arm. Thus, above equations can be written as:

$$
\begin{aligned}
& \frac{d}{d t}\left(N \times \frac{1}{2} C v_{c u}^{2}\right)=i_{a 1} \times \gamma_{1}^{a} \times N \times v_{c u} \Rightarrow C \frac{d v_{c u}}{d t}=i_{a 1} \times \gamma_{1}^{a} \\
& \frac{d}{d t}\left(N \times \frac{1}{2} C v_{c l}^{2}\right)=i_{a 2} \times \gamma_{2}^{a} \times N \times v_{c l} \Rightarrow C \frac{d v_{c l}}{d t}=i_{a 2} \times \gamma_{2}^{a}
\end{aligned}
$$

Recall that $i_{a 1}=I_{d}+\frac{1}{2} i_{a}$ and $i_{a 2}=I_{d}-\frac{1}{2} i_{a}, i_{a}=I_{m} \sin (\omega t+\varphi)$. With insertion functions of the upper and lower arms of phase 'a' $\left(\gamma_{1}^{a}\right.$ and $\left.\gamma_{2}^{a}\right)$ defined as $\gamma_{1}^{a}=\frac{1}{2}\left(\alpha_{d}-m \sin \omega t\right)$ and $\gamma_{2}^{a}=\frac{1}{2}\left(\alpha_{d}+m \sin \omega t\right), \alpha_{d} I_{d}=\frac{1}{4} m I_{m} \cos \varphi$; thus, equation (7) is obtained by adding (5) and (6):

$$
C_{e} \frac{d}{d t}\left(V_{c 1}+V_{c 2}\right)=i_{a 1} \gamma_{1}^{a}+i_{a 2} \gamma_{2}^{a}=\frac{1}{4} m I_{m} \cos (2 \omega t+\varphi)
$$

Where $V_{c l}=N \times v_{c u}$ and $V_{c 2}=N \times v_{c l}$; and $C_{e}=C / N$. Observe that the R.H.S of equations (5) and (6) do not contain dc component, and R.H.S of equation (7) that describes dynamic of the upper and lower arms contains only $2^{\text {nd }}$ harmonic. These indicate that the converter cell capacitor voltage balancing can be maintained around the dc link voltage, and but the cell capacitor voltage level is coupled to the dc link voltage. In order to decouple the cell capacitor voltage level from the dc link voltage level, theoretical equation (7) is abandoned in favour empirical equation in (8):

$$
C_{e} \frac{d}{d t} \frac{1}{2}\left(V_{c 1}+V_{c 2}\right)=\frac{1}{2}\left(i_{a 1}+i_{a 2}\right)=i_{c o m}
$$

Where $C_{e}=C / N$ is the equivalent capacitance per arm, and C is the capacitance per cell. Observe that the R.H.S of equation (8) is a common mode current of the upper and lower arm of phase ' $a$ ' that contains dc component, which provides the ability to change the energy (or voltage) level of the cell capacitors independent of the converter input dc link voltage. The reference common mode current $i_{c o m}^{*}$ is obtained from PI controller that regulates the cell capacitor voltages as:

$$
i_{c o m}^{*}=\alpha_{p}\left[V_{c r e f}-\frac{1}{2}\left(V_{c 1}+V_{c 2}\right)\right]+\alpha_{i} \int\left[V_{c r e f}-\frac{1}{2}\left(V_{c 1}+V_{c 2}\right)\right] d t
$$

The initial gains for the PI controller in (9) are obtained from $\alpha_{p}=2 \xi_{1} \omega_{n 1} C_{e}$ and $\alpha_{i}=\omega_{n 1}^{2} C_{e}$, with damping and natural frequency $\xi_{1}$ and $\omega_{n 1}$ are decided based on time domain specification as previously stated.

Based on above discussions, the control structure for the cell capacitor and common mode current regulation depicted in Figure 2 is constructed. The readers are advised to refer to reference [39] for details of the control design for the remaining controllers depicted in Figure 2.

\section{Performance Evaluation}

Figure 3 shows full-scale symmetrical mono-pole HVDC link that uses $\mathrm{FB}-\mathrm{MMC}$, with each converter terminal $\mathrm{VSC}_{1}$ and $\mathrm{VSC}_{2}$ is rated at $1000 \mathrm{MVA}, \pm 320 \mathrm{kV}$ dc link voltage, and connected to $400 \mathrm{kV}$ ac network through 1000MVA, $300 \mathrm{kV} / 400 \mathrm{kV}$ interfacing transformers. Converter terminals $\mathrm{VSC}_{1}$ and $\mathrm{VSC}_{2}$ are modelled using FB-MMC electromagnetic transient model described in [39], but in this paper, number of FB sub-modules in each arm is set to 101 . Generic control system displayed in Figure 2 is used to control $\mathrm{VSC}_{1}$ and $\mathrm{VSC}_{2}$, with no dedicated controller for $2^{\text {nd }}$ harmonic suppression in converter arms is incorporated in attempt to reduce the overall system complexity.

$\mathrm{VSC}_{1}$ and $\mathrm{VSC}_{2}$ are configured to regulate active power and $\mathrm{dc}$ voltage level at $640 \mathrm{kV}$ (pole-to-pole) respectively, with reactive powers at both stations are set to zero. The parameters of the HVDC link in Figure 3 are listed in Table 1. The de fault survival of the HVDC link in Figure 3 is examined when the cell capacitor voltage balancing of the FB-MMCs used in $\mathrm{VSC}_{1}$ and $\mathrm{VSC}_{2}$ is decoupled from the $\mathrm{dc}$ link during pole-to-ground and pole-to-pole dc faults (with and without converter blocking). 
This paper is a postprint of a paper submitted to and accepted for publication in IEEE Transaction on Power Electronics and is subject to Institution of Electrical and Electronic Engineering Copyright. The copy of record is available at IEEE Xplore Digital Library

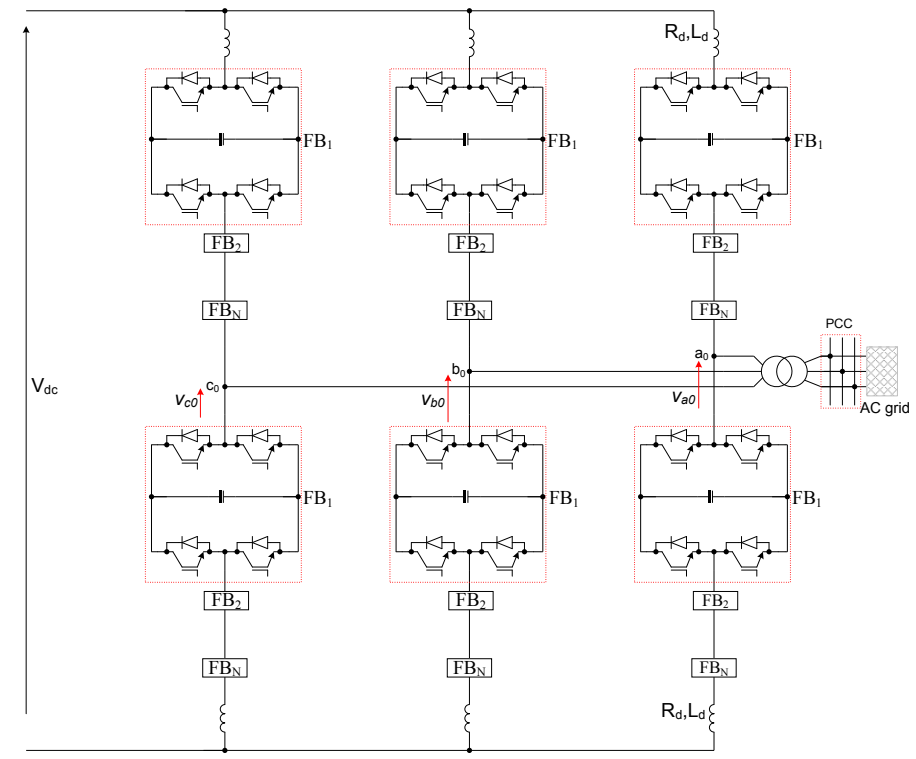

Figure 1: Generic three-phase full-bridge modular multilevel converter

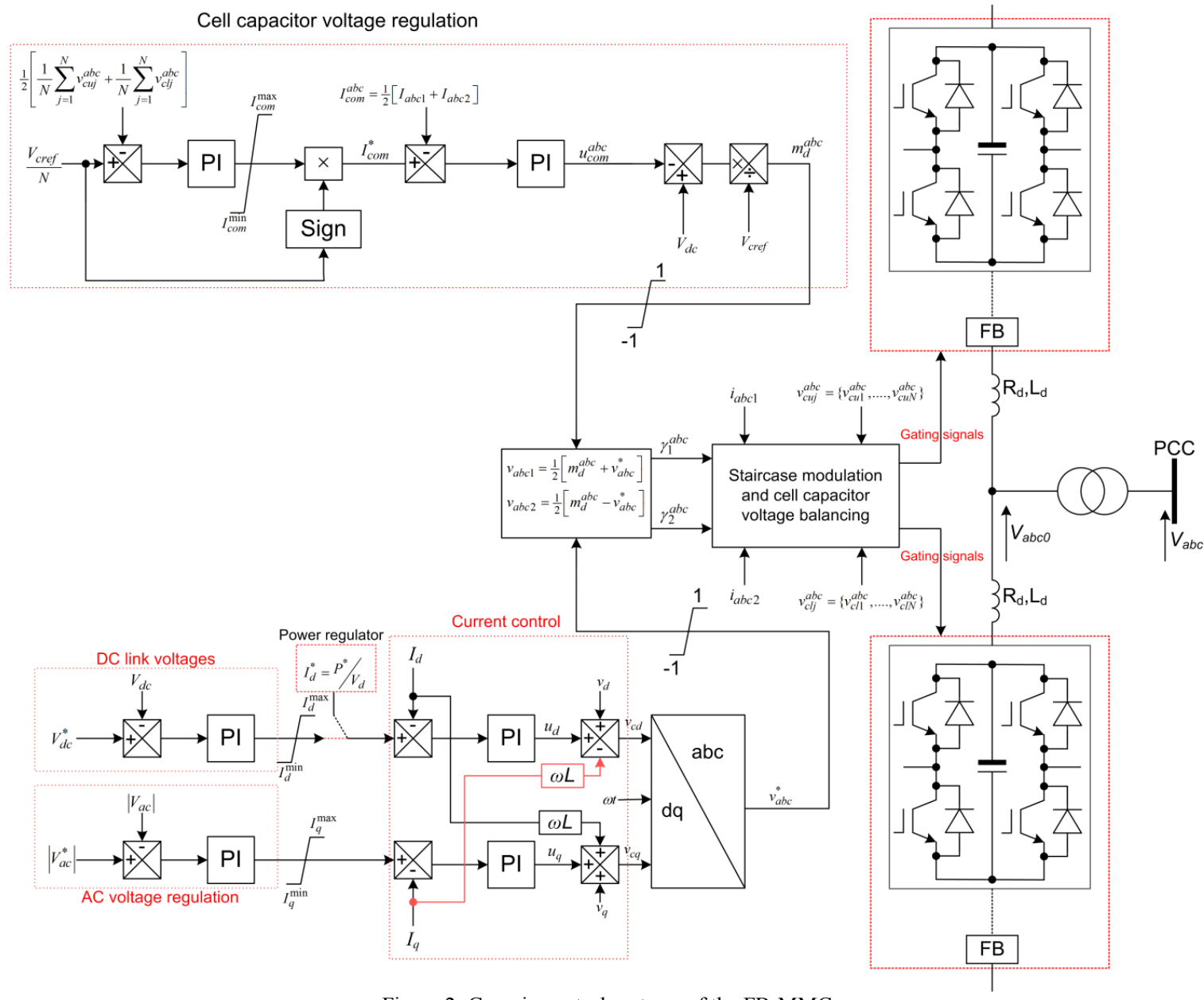

Figure 2: Generic control systems of the FB-MMC 
This paper is a postprint of a paper submitted to and accepted for publication in IEEE Transaction on Power Electronics and is subject to Institution of Electrical and Electronic Engineering Copyright. The copy of record is available at IEEE Xplore Digital Library

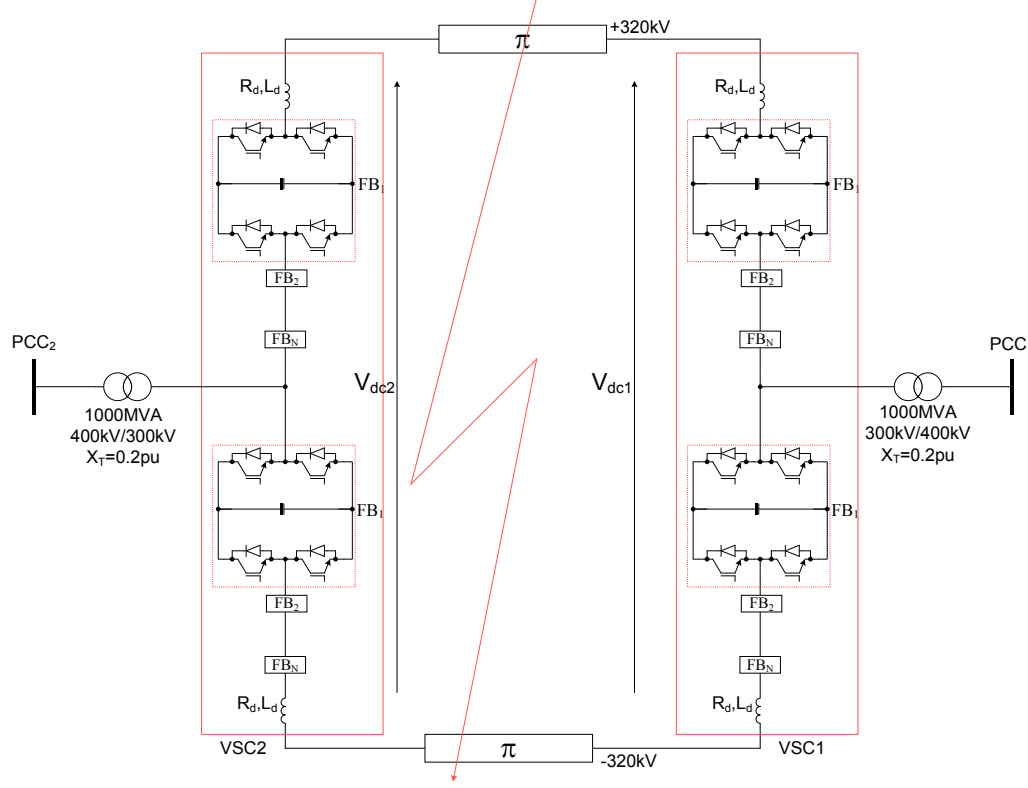

Figure 3: Electromagnetic transient based full-scale model of FB-MMC HVDC link with 101 cells per arm
Table 1: Summary of system parameters

\begin{tabular}{|l|l|}
\hline & \\
\hline dc link voltage (Vdc) & $\pm 320 \mathrm{kV}$ \\
\hline Converter rated ac side voltage & $300 \mathrm{kV}$ \\
\hline Converter rated power & $1052 \mathrm{MVA}$ \\
\hline Converter rated active power & $\pm 1000 \mathrm{MW}$ \\
\hline Converter rated reactive power & $\pm 328 \mathrm{MVAr}$ \\
\hline Number of cells per arm & 101 \\
\hline Capacitance per cell & $4 \mathrm{mF}$ \\
\hline Arm reactance & $50 \mathrm{mH}$ \\
\hline Interfacing transformer rated power & $1052 \mathrm{MVA}$ \\
\hline Interfacing transformer voltage ratio & $300 \mathrm{kV} / 400 \mathrm{kV}$ \\
\hline $\begin{array}{l}\text { Interfacing transformer per unit } \\
\text { leakage reactance }\end{array}$ & $0.2 \mathrm{pu}$ \\
\hline $\begin{array}{l}\text { Interfacing transformer per unit } \\
\text { resistance }\end{array}$ & $0.0002 \mathrm{pu}$ \\
\hline DC cable resistance & $0.01 \Omega / \mathrm{km}$ \\
\hline DC cable inductance & $0.8 \mathrm{mH} / \mathrm{km}$ \\
\hline DC cable capacitance & $0.25 \mu \mathrm{F} / \mathrm{km}$ \\
\hline
\end{tabular}

exchange with $\mathrm{PCC}_{1}$ and $\mathrm{PCC}_{2}$, and their corresponding ac side currents measured at $\mathrm{PCC}_{1}$ and $\mathrm{PCC}_{2}$. Figure 4 (e) and (f) show arm currents of the $\mathrm{VSC}_{1}$ and $\mathrm{VSC}_{2}$. Figure $4(\mathrm{~g})$ and $(\mathrm{h})$ show samples of the dc link voltage (pole-to-pole) and current measured at the terminals of $\mathrm{VSC}_{2}$. Observe that a successful reduction of the dc link voltage is achieved, with the current stresses in $\mathrm{VSC}_{1}$ and $\mathrm{VSC}_{2}$ upper and lower arms and in their ac sides remain fully controllable. This illustrative example has demonstrated the possibility of continuous operation of the FB-MMC HVDC link when one of the its positive or negative poles is subjected to permanent pole-to-ground dc fault. Figure 4 (i) and (j) show the cell capacitor voltages of $\mathrm{VSC}_{1}$ and $\mathrm{VSC}_{2}$ are decoupled from the dc link voltage and well regulated around $(640 \mathrm{kV} / 101 \approx 6.37 \mathrm{kV})$ as in pre-fault condition. The significance of this work is that it addresses the main weakness in all symmetrical mono-pole HVDC links currently in operation (inability to operate during pole-toground dc fault as the surge arresters and dc cable insulation of the healthy pole will breakdown from excessive voltage stresses, see Figure $4(\mathrm{k})$ ).

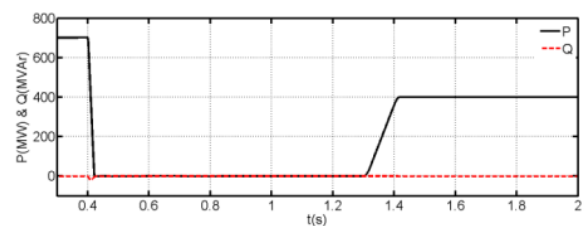

(a) Active and reactive power $\mathrm{VSC}_{1}$ exchanges with $\mathrm{PCC}_{1}$

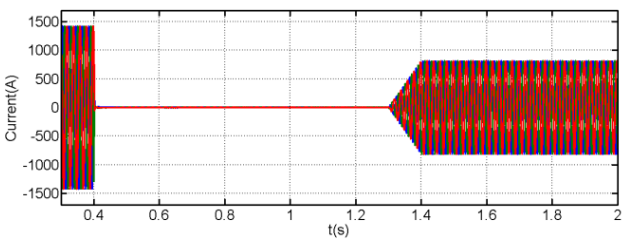

(c) $\mathrm{AC}$ currents $\mathrm{VSC}_{1}$ injects into $\mathrm{PCC}_{1}$

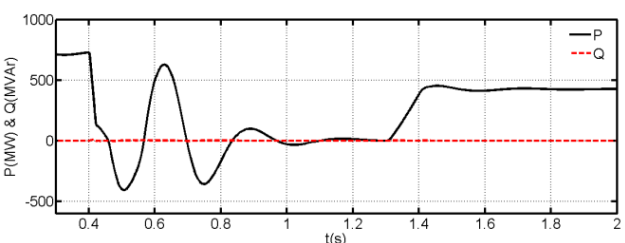

(b) Active and reactive power $\mathrm{VSC}_{2}$ exchanges with $\mathrm{PCC}_{2}$

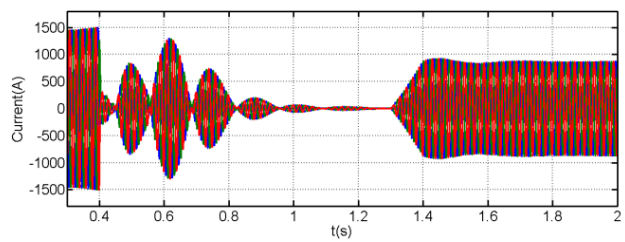

(d) $\mathrm{AC}$ currents $\mathrm{VSC}_{2}$ injects into $\mathrm{PCC}_{2}$ 
This paper is a postprint of a paper submitted to and accepted for publication in IEEE Transaction on Power Electronics and is subject to Institution of Electrical and Electronic Engineering Copyright. The copy of record is available at IEEE Xplore Digital Library

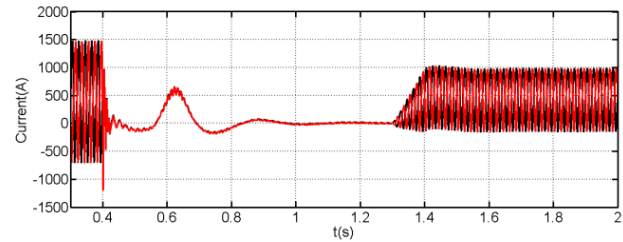

(e) $\mathrm{VSC}_{1}$ phase 'a' upper and lower arm currents

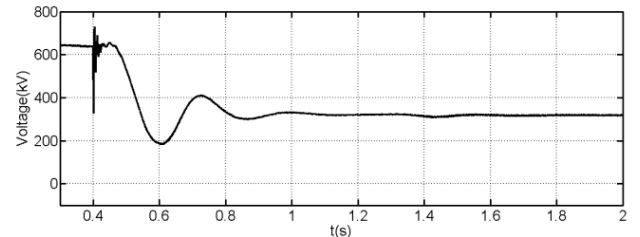

(g) $\quad \mathrm{VSC}_{2} \mathrm{dc}$ link voltage

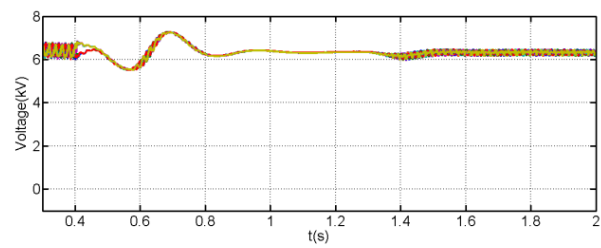

(i) $\quad \mathrm{VSC}_{1}$ phase 'a' upper and lower arms cell capacitor voltages



(f) $\quad \mathrm{VSC}_{2}$ phase ' $\mathrm{a}$ ' upper and lower arm currents

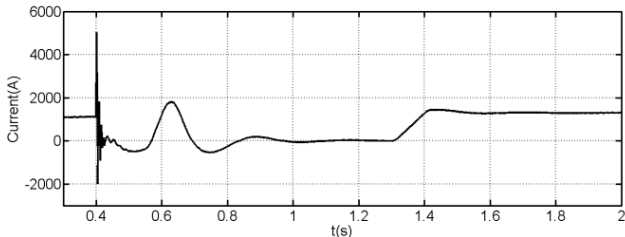

(h) Sample of the de link current measured at the terminals of $\mathrm{VSC}_{2}$ (positive pole)

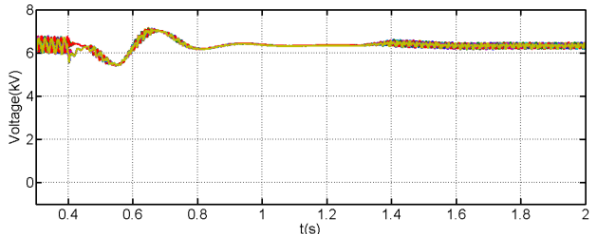

(j) $\quad \mathrm{VSC}_{2}$ phase ' $\mathrm{a}$ ' upper and lower arms cell capacitor voltages

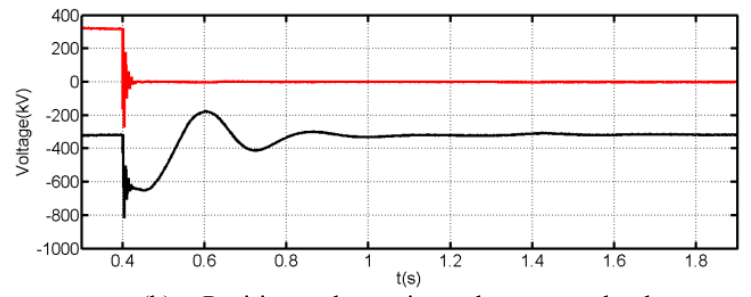

(k) Positive and negative pole to ground voltages

Figure 4: Waveforms obtained when HVDC link based on FB-MMC is subjected to pole-to-ground dc fault at the middle of the link

(B) Pole-to-pole dc fault

(i) When $\mathrm{VSC}_{1}$ and $\mathrm{VSC}_{2}$ are blocked during fault

This section exploits the dc fault reverse blocking and controlled recharge capabilities of the FB-MMC to improve dc fault survival of symmetrical mono-pole HVDC link, while keeping the current and voltage stresses on converter stations switching devices and passive components within tolerable limits. For illustration, the HVDC link in Figure 3 is subjected to a temporary pole-to-pole dc fault at the middle of the dc line that connects $\mathrm{VSC}_{1}$ to $\mathrm{VSC}_{2}$ at $\mathrm{t}=0.4 \mathrm{~s}$, with $100 \mathrm{~ms}$ fault duration. In pre-fault condition, the HVDC link in Figure 3 is set to export $700 \mathrm{MW}$ from $\mathrm{PCC}_{1}$ to $\mathrm{PCC}_{2}$, and the transmitted power is reduced to zero and converter switches are blocked immediately when the fault is detected. After fault clearance at $\mathrm{t}=0.5 \mathrm{~s}, \mathrm{VSC}_{1}$ and $\mathrm{VSC}_{2}$ switches are unlocked, and $\mathrm{VSC}_{2}$ is commanded to perform a controlled recharge of the dc link to $640 \mathrm{kV}$ before power transmission is resumed. At $\mathrm{t}=1.3 \mathrm{~s}, \mathrm{VSC}_{1}$ is commanded to restore the power exchange between the two ac networks gradually to pre-fault value.

Figure 5 (a) and (b), (c) and (d), and (e) and (f) show active and reactive powers $\mathrm{VSC}_{1}$ and $\mathrm{VSC}_{2}$ exchange with their corresponding ac networks, ac current waveforms measured at $\mathrm{PCC}_{1}$ and $\mathrm{PCC}_{2}$, and arm currents of the $\mathrm{VSC}_{1}$ and $\mathrm{VSC}_{2}$ respectively. These waveforms have shown that the link being studied is able to recover from pole-to-pole $\mathrm{dc}$ fault, with currents at $\mathrm{PCC}_{1}$ and $\mathrm{PCC}_{2}$, and switching devices of $\mathrm{VSC}_{1}$ and $\mathrm{VSC}_{2}$ are tightly regulated within the levels that can be tolerated by the commercially available
IGBTs. Figure $5(\mathrm{~g})$ and $(\mathrm{h})$ show samples of the de link voltage and current measured at the terminals of $\mathrm{VSC}_{2}$. Observe that the HVDC link being studied briefly lost control due to the transients experienced when converter switches are unblocked promptly and the delay time introduced by the response time of individual controllers, and shortly afterward the link is able to perform a controlled recharge of the link, with the current associated with the recharging of the dc line stray capacitors are tightly controlled, including that in the converter arms. Figure 5 (i) and $(\mathrm{j})$ show the voltage balance of the cell capacitors of $\mathrm{VSC}_{1}$ and $\mathrm{VSC}_{2}$ are well maintained, including during controlled recharge of the dc link.

\section{(ii) When $\mathrm{VSC}_{1}$ and $\mathrm{VSC}_{2}$ are not blocked during dc fault}

This subsection investigates the possibility of riding a temporary pole-to-pole dc fault studied in subsection $B$-(i) when $\mathrm{VSC}_{1}$ and $\mathrm{VSC}_{2}$ are not blocked, and their cell capacitor voltages are exploited in a manner to be seen by their respective ac sides as virtual dc links. Exploiting this feature allows the ac currents $\mathrm{VSC}_{1}$ and $\mathrm{VSC}_{2}$ exchange with $\mathrm{PCC}_{1}$ and $\mathrm{PCC}_{2}$ to be controllable despite the collapse of their physical dc link voltage. Figure 6 displays selected waveforms obtained when the simulated case in $B$ - $(i)$ is repeated, with $\mathrm{VSC}_{1}$ and $\mathrm{VSC}_{2}$ remain unblocked. Figure 6 (a) and (b) show with the control system in Figure 2, the HVDC link being studied is able to ride-through solid poleto-pole dc fault, with ac currents associated with the discharge and recharge of the dc line stray capacitors are 
This paper is a postprint of a paper submitted to and accepted for publication in IEEE Transaction on Power Electronics and is subject to Institution of Electrical and Electronic Engineering Copyright. The copy of record is available at IEEE Xplore Digital Library

tightly controlled. But the plots for the upper and lower arm currents of $\mathrm{VSC}_{1}$ and $\mathrm{VSC}_{2}$ in Figure 6 (c) and (d) have shown that the current stresses in the converter arms, which will be seen by the semiconductor switches, are dominated by the transient discharge currents of the dc line stray capacitors. Figure 6 (e) and (f) show when $\mathrm{VSC}_{1}$ and $\mathrm{VSC}_{2}$ are not blocked, their cell capacitor voltages exhibit large disturbances as result of large unipolar dc fault currents that flow through the sub-module capacitors. Although the

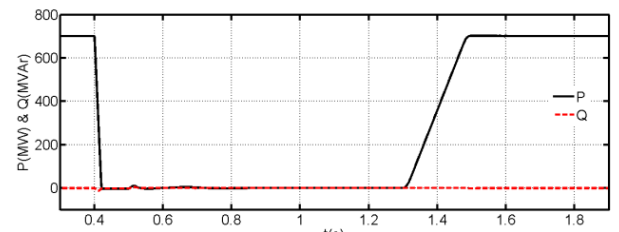

(a) Active and reactive power $\mathrm{VSC}_{1}$ exchanges with $\mathrm{PCC}_{1}$

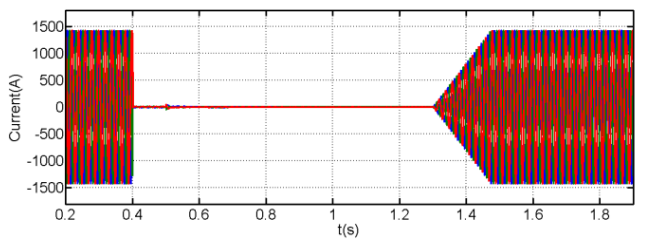

(c) $\mathrm{AC}$ current waveforms $\mathrm{VSC}_{1}$ exchanges with $\mathrm{PCC}_{1}$

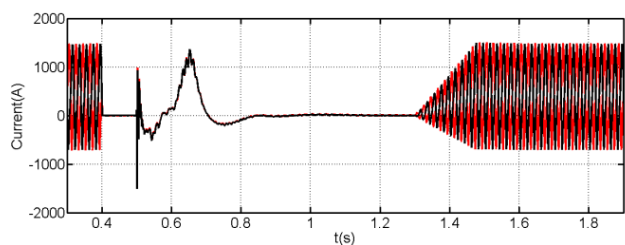

(e) $\mathrm{VSC}_{1}$ phase 'a' upper and lower arm currents

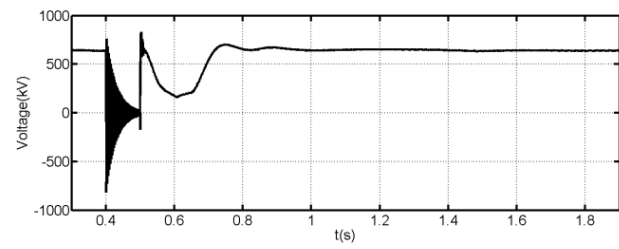

(g) Sample of the dc link voltage measured at the terminals of $\mathrm{VSC}_{2}$

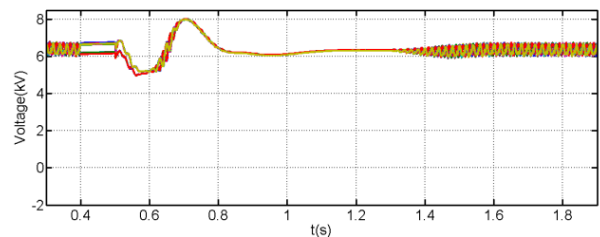

(i) Phase ' $a$ ' upper and lower arms cell capacitor voltages of the $\mathrm{VSC}_{1}$

Figure 5: Waveforms obtained when HVDC link based on FB-MMC is subjected to pole-to-pole dc fault at the middle of the link



(a) Current waveforms $\mathrm{VSC}_{1}$ injects into $\mathrm{PCC}_{1}$

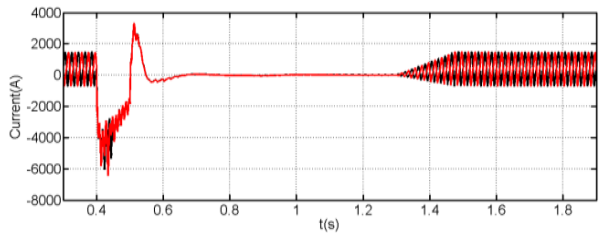

simulated case (B)-(ii) has shown that the semiconductor switches are less likely to survive such excessive current stresses when converters are not blocked, riding dc fault without converter blocking may be possible in relatively short overhead HVDC links, where the line distributed capacitances are negligible. Figure $6(\mathrm{~g})$ and $(\mathrm{h})$ show sample of the dc link current and de link voltage measured at $\mathrm{VSC}_{2}$ terminals.

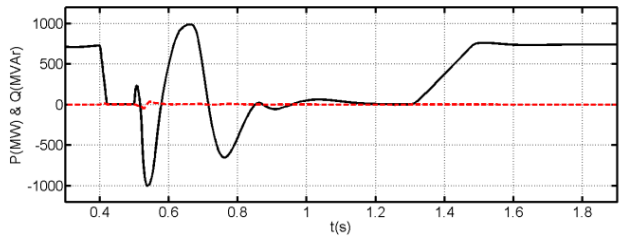

(b) Active and reactive power $\mathrm{VSC}_{2}$ exchanges with $\mathrm{PCC}_{2}$



(d) $\mathrm{AC}$ current waveforms $\mathrm{VSC}_{2}$ exchanges with $\mathrm{PCC}_{2}$

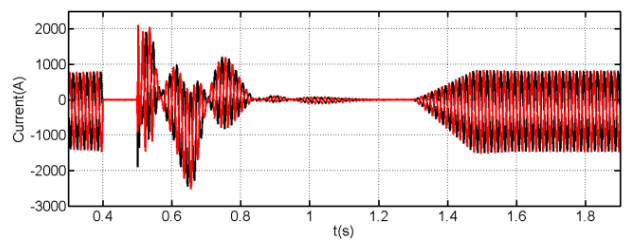

(f) $\quad \mathrm{VSC}_{2}$ phase 'a' upper and lower arm currents

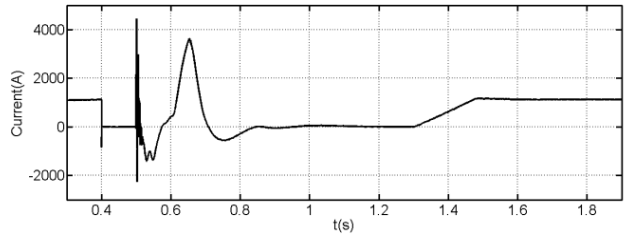

(h) Sample of the dc link current measured at the terminal of $\mathrm{VSC}_{2}$ (positive pole)

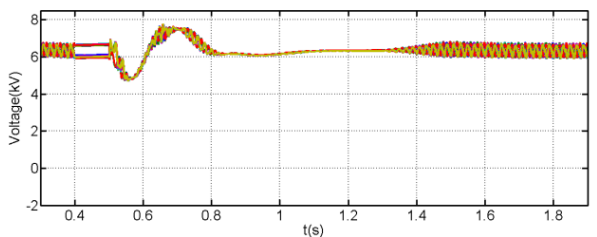

(j) Phase 'a' upper and lower arms cell capacitor voltages of the $\mathrm{VSC}_{2}$

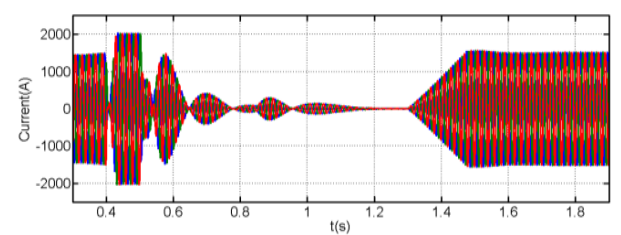

(b) Current waveforms $\mathrm{VSC}_{2}$ injects into $\mathrm{PCC}_{2}$

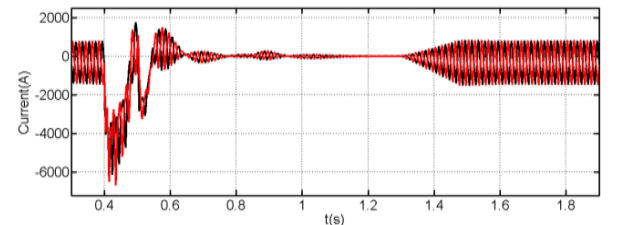


This paper is a postprint of a paper submitted to and accepted for publication in IEEE Transaction on Power Electronics and is subject to Institution of Electrical and Electronic Engineering Copyright. The copy of record is available at IEEE Xplore Digital Library

(c) $\mathrm{VSC}_{1}$ phase 'a' upper and lower arm currents

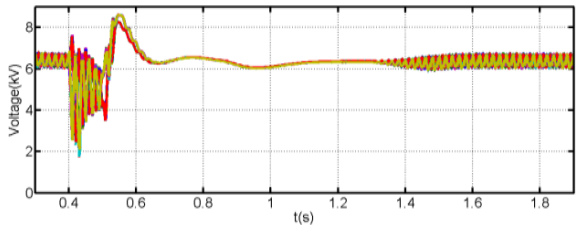

(e) $\mathrm{VSC}_{1}$ cell capacitor voltages (phase 'a')

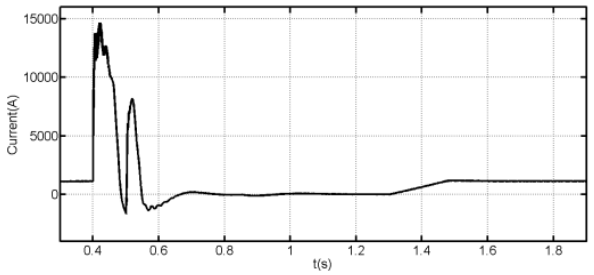

(g) Sample of the dc link current measured at the terminal of $\mathrm{VSC}_{2}$

(positive pole)
Figure 6: Waveforms obtained when HVDC link based on FB-MMC is remain unblocked during fault

\section{CONCLUSIONS}

This paper presented comprehensive discussions of the underlying theory, which is later exploited to control FBMMC when used in a symmetrical mono-pole HVDC link in attempt to improve its dc fault survival. It has been shown that when the regulation of the cell capacitor voltages is decoupled from the converter dc link voltage, converter stations of the HVDC remain controllable even though when its physical dc link voltage is collapsed to zero. Moreover, it has been shown that the number of sub-modules to be is directly link to the dc bias magnitude of the insertion function of each phase, and this feature is exploited to voltage. The theoretical discussions presented in section II have been substantiated using simulation of full-scale HVDC link that uses FB-MMC with 101 sub-modules per arm, considering the cases of pole-to-ground and pole-topole dc faults. The presented results have shown that the FB-MMC offers number of invaluable features that are well suited for point-to-point and multi-terminal HVDC transmission systems.

\section{REFERENCES}

[1] F. Deng and Z. Chen, "A Control Method for Voltage Balancing in Modular Multilevel Converters," Power Electronics, IEEE Transactions on, vol. 29, pp. 66-76, 2014.

[2] S. Debnath and M. Saeedifard, "A New Hybrid Modular Multilevel Converter for Grid Connection of Large Wind Turbines," Sustainable Energy, IEEE Transactions on, vol. PP, pp. 1-14, 2013.

[3] G. P. Adam, K. H. Ahmed, S. J. Finney, K. Bell, and B. W. Williams, "New Breed of Network Fault-Tolerant Voltage-Source-Converter HVDC Transmission System," Power Systems, IEEE Transactions on, vol. 28, pp. 335-346, 2013.

[4] G. Adam, I. Abdelsalam, K. Ahmed, and B. Williams, "Hybrid Multilevel Converter With Cascaded H-bridge Cells for HVDC Applications: Operating Principle and Scalability," Power Electronics, IEEE Transactions on, vol. PP, pp. 1-1, 2014.

[5] G. P. Adam; K. H. Ahmed;, and B. W. Williams, "Mixed cells 2014.

[6] G. P. Adam and B. W. Williams, "New emerging voltage source converter for high-voltage application: hybrid multilevel converter with de side H-bridge chain links," Generation, Transmission \& Distribution, IET, vol. 8, pp. 765-773, 2014. inserted in power path with positive and negative polarities enable operation of FB-MMC HVDC link with variable dc modular multilevel converter," presented at the IEEE International Symposium on Industrial Electronics (ISIE 2014), ISTANBUL, (d) $\mathrm{VSC}_{2}$ phase ' $\mathrm{a}$ ' upper and lower arm currents

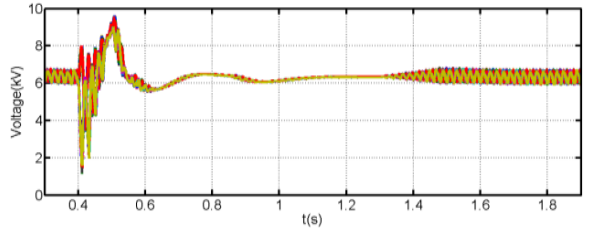

(f) $\mathrm{VSC}_{2}$ cell capacitor voltages (phase ' $\mathrm{a}$ ')



(h) Sample of the pole-to-pole dc link voltage measured at the terminals of $\mathrm{VSC}_{2}$
bjected to pole-to-pole de fault at the middle of the link, with VSC1 and VSC2

[7] Y. Zhang, G. Adam, S. Finney, and B. Williams, "Improved pulsewidth modulation and capacitor voltage-balancing strategy for a scalable hybrid cascaded multilevel converter," Power Electronics, IET, vol. 6, 2013.

[8] G. P. Adam, S. J. Finney, and B. W. Williams, "Hybrid converter with ac side cascaded $\mathrm{H}$-bridge cells against $\mathrm{H}$-bridge alternative arm modular multilevel converter: steady-state and dynamic performance," Generation, Transmission \& Distribution, IET, vol. 7, 2013.

[9] L. Xiaoqian, S. Qiang, L. Wenhua, R. Hong, X. Shukai, and L. Licheng, "Protection of Nonpermanent Faults on DC Overhead Lines in MMC-Based HVDC Systems," Power Delivery, IEEE Transactions on, vol. 28, pp. 483-490, 2013.

[10] H. Saad, J. Peralta, S. Dennetiere, J. Mahseredjian, J. Jatskevich, J. A. Martinez, et al., "Dynamic Averaged and Simplified Models for MMC-Based HVDC Transmission Systems," Power Delivery, IEEE Transactions on, vol. 28, pp. 1723-1730, 2013.

[11] X. Jianzhong, Z. Chengyong, L. Wenjing, and G. Chunyi, "Accelerated Model of Modular Multilevel Converters in PSCAD/EMTDC," Power Delivery, IEEE Transactions on, vol. 28, pp. 129-136, 2013.

[12] S. Shuai, P. W. Wheeler, J. C. Clare, and A. J. Watson, "Fault Detection for Modular Multilevel Converters Based on Sliding Mode Observer," Power Electronics, IEEE Transactions on, vol. 28, pp. 4867-4872, 2013.

[13] M. Ji-Woo, K. Chun-Sung, P. Jung-Woo, K. Dea-Wook, and K. Jang-Mok, "Circulating Current Control in MMC Under the Unbalanced Voltage," Power Delivery, IEEE Transactions on, vol. 28, pp. 1952-1959, 2013.

[14] C. Heising, T. Schrader, R. Bartelt, V. Staudt, and A. Steimel, "Polerestraining control for Modular Multilevel Converters in electric-ship applications," in Electric Ship Technologies Symposium (ESTS), 2013 IEEE, 2013, pp. 366-371.

[15] J. Qin, M. Saeedifard, A. Rockhill, and R. Zhou, "Hybrid Design of Modular Multilevel Converters for HVDC Systems Based on Various Submodule Circuits," Power Delivery, IEEE Transactions on, vol. PP, pp. 1-1, 2014.

[16] I. A. Gowaid, G. P. Adam, A. M. Massoud, S. Ahmed, D. Holliday, and B. W. Williams, "Quasi Two-Level Operation of Modular Multilevel Converter for Use in a High-Power DC Transformer with DC Fault Isolation Capability," Power Electronics, IEEE Transactions on, vol. PP, pp. 1-1, 2014.

[17] T. Qingrui, X. Zheng, and X. Lie, "Reduced switching-frequency modulation and circulating current suppression for modular multilevel converters," in Transmission and Distribution Conference and Exposition (T\&D), 2012 IEEE PES, 2012, pp. 1-1.

[18] S. Xu, H. Rao, Q. Song, W. Liu, and X. Zhao, "Experimental research of MMC based VSC-HVDC system for wind farm integration," in Industrial Electronics (ISIE), 2013 IEEE International Symposium on, 2013, pp. 1-5.

[19] Q. Jiangchao and M. Saeedifard, "Predictive Control of a Modular Multilevel Converter for a Back-to-Back HVDC System," Power Delivery, IEEE Transactions on, vol. 27, pp. 1538-1547, 2012. 
This paper is a postprint of a paper submitted to and accepted for publication in IEEE Transaction on Power Electronics and is subject to Institution of Electrical and Electronic Engineering Copyright. The copy of record is available at IEEE Xplore Digital Library

[20] M. K. Bucher and C. M. Franck, "Contribution of Fault Current Sources in Multiterminal HVDC Cable Networks," Power Delivery, IEEE Transactions on, vol. 28, pp. 1796-1803, 2013.

[21] D. Fujin and C. Zhe, "Design of Protective Inductors for HVDC Transmission Line Within DC Grid Offshore Wind Farms," Power Delivery, IEEE Transactions on, vol. 28, pp. 75-83, 2013.

[22] T. Jonsson, P. Lundberg, S. Maiti, and Y. Jiang-Häfner, "Converter Technologies and Functional Requirements for Reliable and Economical HVDC Grid Design," presented at the Cigre Canada, Calgary, Canada, 2013.

[23] D. Schmitt, Y. Wang, T. Weyh, and R. Marquardt, "DC-side fault current management in extended multiterminal-HVDC-grids," in Systems, Signals and Devices (SSD), 2012 9th International MultiConference on, 2012, pp. 1-5.

[24] C. M. Franck, "HVDC Circuit Breakers: A Review Identifying Future Research Needs," Power Delivery, IEEE Transactions on, vol. 26, pp. 998-1007, 2011.

[25] S. Kenzelmann, A. Rufer, D. Dujic, F. Canales, and Y. R. De Novaes, "A versatile DC/DC converter based on Modular Multilevel Converter for energy collection and distribution," in Renewable Power Generation (RPG 2011), IET Conference on, 2011, pp. 1-6.

[26] G. P. Adam, S. J. Finney, K. Bell, and B. W. Williams, "Transient capability assessments of HVDC voltage source converters," in Power and Energy Conference at Illinois (PECI), 2012 IEEE, 2012, pp. 1-8.

[27] Y. Zhang, G. Adam, T. Lim, S. Finney, and B. Williams, "Hybrid Multilevel Converter: Capacitor Voltage Balancing Limits and its Extension," Industrial Informatics, IEEE Transactions on, vol. PP, pp. 1-1, 2012

[28] G. P. Adam;, K. H. Ahmed;, S. J. Finney;, and B. W. Williams, "HBRIDGE MODULAR MULTILEVEL CONVERTER (M2C) FOR HIGH-VOLTAGE APPLICATIONS," presented at the 21st International Conference on Electricity Distribution (Cired), Frankfurt, 2011.

[29] S. Debnath, Q. Jiangchao, B. Bahrani, M. Saeedifard, and P. Barbosa, "Operation, Control, and Applications of the Modular Multilevel Converter: A Review," Power Electronics, IEEE Transactions on, vol. 30, pp. 37-53, 2015.

[30] M. Hagiwara and H. Akagi, "Control and Experiment of PulsewidthModulated Modular Multilevel Converters," Power Electronics, IEEE Transactions on, vol. 24, pp. 1737-1746, 2009.

[31] N. Thitichaiworakorn, M. Hagiwara, and H. Akagi, "Experimental Verification of a Modular Multilevel Cascade Inverter Based on Double-Star Bridge Cells," Industry Applications, IEEE Transactions on, vol. 50, pp. 509-519, 2014.

[32] A. Nami, L. Wang, and F. Dijkhuizen, "Five level cross connected cell for cascaded converters," presented at the European Power Electronics and Applications Conference (EPE), Lille, France, 2013.

[33] Lu, x, T. th, M. M. C. Merlin, T. C. Green, C. D. Barker, et al., "Performance of a DC/AC/DC VSC system to interconnect HVDC systems," in $A C$ and DC Power Transmission (ACDC 2012), 10th IET International Conference on, 2012, pp. 1-6.

[34] M. M. C. Merlin, T. C. Green, P. D. Mitcheson, D. R. Trainert, D. R. Critchleył, and R. W. Crookesł, "A New Hybrid Multi-Level Voltage-Source Converter with DC Fault Blocking Capability," in IET ACDC2010, London,UK, 2010.

[35] Z. Rong, X. Lie, Y. Liangzhong, and B. W. Williams, "Design and Operation of a Hybrid Modular Multilevel Converter," Power Electronics, IEEE Transactions on, vol. 30, pp. 1137-1146, 2015.

[36] A. Nami, L. Wang, and F. Dijkhuizen, "Five level cross connected cell for cascaded converters," presented at the European Power Electronics (EPE2013), Lille, France, 2013.

[37] R. Marquardt, "Modular Multilevel Converter topologies with DCShort circuit current limitation," in Power Electronics and ECCE Asia (ICPE \& ECCE), 2011 IEEE 8th International Conference on, 2011, pp. 1425-1431.

[38] R. Marquardt, "Modular Multilevel Converter: An universal concept for HVDC-Networks and extended DC-Bus-applications," in Power Electronics Conference (IPEC), 2010 International, 2010, pp. 502507.

[39] G. P. Adam and B. W. Williams, "Half and Full-Bridge Modular Multilevel Converter Models forSimulations of Full-Scale HVDC Links and Multi-terminal DC grids," Emerging and Selected Topics in Power Electronics, IEEE Journal of, vol. PP, pp. 1-1, 2014. 